\title{
Microglia-Dependent Alteration of Glutamatergic Synaptic Transmission and Plasticity in the Hippocampus during Peripheral Inflammation
}

\author{
-Kiarash Riazi, Michael A. Galic, ${ }^{-A m a n d a}$ C. Kentner, Aylin Y. Reid, Keith A. Sharkey, and ${ }^{-}$Quentin J. Pittman \\ Hotchkiss Brain Institute and Snyder Institute for Chronic Diseases, Department of Physiology and Pharmacology, Cumming School of Medicine, \\ University of Calgary, Calgary, Alberta, Canada T2N 4N1
}

Peripheral inflammatory diseases are often associated with behavioral comorbidities including anxiety, depression, and cognitive dysfunction, but the mechanism for these is not well understood. Changes in the neuronal and synaptic functions associated with neuroinflammation may underlie these behavioral abnormalities. We have used a model of colonic inflammation induced by $2,4,6-$ trinitrobenzenesulfonic acid in Sprague Dawley rats to identify inflammation-induced changes in hippocampal synaptic transmission. Hippocampal slices obtained $4 \mathrm{~d}$ after the induction of inflammation revealed enhanced Schaffer collateral-induced excitatory field potentials in CA1 stratum radiatum. This was associated with larger-amplitude $\mathrm{MEPSCs}$, but unchanged mEPSC frequencies and pairedpulse ratios, suggesting altered postsynaptic effects. Both AMPA- and NMDA-mediated synaptic currents were enhanced, and analysis of AMPA-mediated currents revealed increased contributions of GluR2-lacking receptors. In keeping with this, both transcripts and protein levels of the GluR2 subunit were reduced in hippocampus. Both long-term potentiation (LTP) and depression (LTD) were significantly reduced in hippocampal slices taken from inflamed animals. Chronic administration of the microglial/macrophage activation inhibitor minocycline to the inflamed animals both lowered the level of the cytokine tumor necrosis factor $\alpha$ in the hippocampus and completely abolished the effect of peripheral inflammation on the field potentials and synaptic plasticity (LTP and LTD). Our results reveal profound synaptic changes caused by a mirror microglia-mediated inflammatory response in hippocampus during peripheral organ inflammation. These synaptic changes may underlie the behavioral comorbidities seen in patients.

Key words: cytokine; glutamate; LTD; LTP; microglia; neuroinflammation

\section{Introduction}

Peripheral inflammation is a feature of many diseases, including inflammatory bowel disease (Häuser et al., 2011), rheumatoid arthritis (Maini et al., 2004; Mayoux-Benhamou, 2006), and inflammatory liver disease (Gralnek et al., 2000; Butterworth, 2013; D'Mello and Swain, 2014), and is often associated with marked behavioral changes, including mood disorders, fatigue, cognitive and memory dysfunction, and sleep disturbances. Moreover, the inflammation is capable of aggravating other neurological and neuropsy-

Received Oct. 27, 2014; revised Jan. 22, 2014; accepted Feb. 16, 2015.

Author contributions: K.R., K.A.S., and Q.J.P. designed research; K.R., M.A.G., A.C.K., and A.Y.R. performed research; K.R., M.A.G., A.C.K., and A.Y.R. analyzed data; K.R., M.A.G., K.A.S., and Q.J.P. wrote the paper.

This work was supported by Alberta Innovates Health Solutions (AI-HS), the Canadian Institutes of Health Research (CIHR), the Crohn's and Colitis Foundation of Canada Chair in IBD Research, and personnel support awards from Alberta Heritage Foundation for Medical Research/AI-HS (K.R., M.A.G., A.C.K., A.Y.R., K.A.S., and Q.J.P.), the Savoy Foundation (K.R.), the Hotchkiss Brain Institute (A.Y.R.), and the (IHR (A.Y.R.). We thank C. M. Keenen, L. Bauce, and Dr. M. Tsutsui for technical assistance.

The authors declare no competing financial interests.

Correspondence should be addressed to Dr. Quentin J. Pittman, Hotchkiss Brain Institute, Department of Physiology and Pharmacology, Cumming School of Medicine, University of Calgary, 3330 Hospital Drive Northwest, Calgary, AB, Canada T2N 4N1. E-mail: pittman@ucalgary.ca.

A.C. Kentner's present address: MCPHS University (formerly Massachusetts College of Pharmacy and Health Sciences), Boston, MA 02115

DOI:10.1523/JNEUROSCI.4485-14.2015

Copyright $\odot 2015$ the authors $\quad 0270-6474 / 15 / 354942-11 \$ 15.00 / 0$ chiatric conditions, including seizure disorders (Vezzani et al., 2013), major depression (Raison et al., 2006), Alzheimer's disease (Ferrari and Tarelli, 2011), multiple sclerosis (Benson and Kerr, 2014), Parkinson's disease (Collins et al., 2012), and stroke (Ferrari and Tarelli, 2011). These comorbid effects can have considerable impact on both health and the quality of life of the patients.

The behavioral manifestations associated with peripheral inflammation clearly indicate CNS involvement; thus, a number of mechanisms have been suggested to underlie the communication between these peripheral inflammatory conditions and the brain (Walker et al., 2014). Peripheral tissue inflammation results in the production of proinflammatory cytokines that signal to the brain via cytokine receptors at the blood-brain barrier, within circumventricular organs or on sensory afferents. There is now compelling evidence that the cytokines generated during peripheral inflammation activate a secondary, mirror inflammatory response in the brain that is characterized by activation of microglia and production of proinflammatory cytokines, most importantly, tumor necrosis factor $\alpha$ (TNF $\alpha$ ), interleukin (IL)- $1 \beta$, and IL-6 (Quan et al., 1998; D’Mello et al., 2013; Thomson et al., 2014). These cytokines have profound effects on synaptic transmission and synaptic plasticity (for review, see Pickering and O'Connor, 2007), effects that most likely underlie the cognitive dysfunction, altered behavior, and other interactions with preex- 
isting pathologies seen in peripheral inflammatory disease (Raison et al., 2006; Galic et al., 2012; Santello and Volterra, 2012; Nisticò et al., 2013; Camara et al., 2015). There is accumulating evidence that alterations in glutamatergic transmission underlie some of these behaviors (for review, see Walker et al., 2014).

In a rat model of inflammatory colitis, we previously reported reduced thresholds to chemically induced seizures in vivo and increased excitability of the hippocampus in vitro (Riazi et al., 2008). The increased excitability is mediated by activated microglia and production of TNF $\alpha$ in the hippocampus. However, the neuronal and synaptic changes that correlate with such increased excitability are unknown. Previous work indicates that TNF $\alpha$ alters expression of glutamate (Stellwagen and Malenka, 2006) and GABA (Pribiag and Stellwagen, 2013) receptors in vitro. In addition, direct application of proinflammatory cytokines to hippocampal slices in vitro alters the ability of excitatory synapses to display long-term potentiation (LTP; Pickering and O'Connor, 2007), a type of plasticity associated with learning and memory. Following up on our previous studies revealing an elevation of inflammatory cytokines in the brain (Riazi et al., 2008), we hypothesize that glutamatergic synaptic transmission and plasticity are altered during inflammatory colitis due to microglial activation. In a rat model of inflammatory colitis, we now report changes in hippocampal synaptic transmission associated with a profound reduction in synaptic plasticity.

\section{Materials and Methods}

Peripheral inflammation model. Adult male Sprague Dawley rats (Charles River Laboratories) weighing 200-250 g were used in this study. The animals had ad libitum access to food and water and were kept at a $20-21^{\circ} \mathrm{C}$ room temperature under specified pathogen-free conditions with a $12 \mathrm{~h}$ light/dark cycle and light onset at 07:00 A.M. All the experiments were conducted in accordance with the Canadian Council on Animal Care regulations and approval of the University of Calgary Animal Care Committee. Inflammatory colitis was induced by a single intracolonic administration of 2,4,6-trinitrobenzenesulfonic acid (TNBS; 0.5 $\mathrm{ml}, 50 \mathrm{mg} / \mathrm{ml}$, in $50 \%$ ethanol/saline mixture) or saline as a control through a flexible cannula to $\sim 8 \mathrm{~cm}$ proximal to the anus, under brief isoflurane anesthesia. We showed previously that this induces an inflammation of the colon that peaks at $4 \mathrm{~d}$ and resolves over a $10 \mathrm{~d}$ period (Miampamba et al., 1998; Riazi et al., 2008). Unless indicated otherwise, experiments were performed on day 4. For all experiments, the colons were examined and quantitatively scored for the severity of colonic inflammation [total score from length of ulceration (score of 5 for $1 \mathrm{~cm}$ of ulcer, and then add 1 for every extra $1 \mathrm{~cm}$ ), bowel adhesions (absent, 0 ; mild, 1; severe, 2), and diarrhea ( 1 if present)]; myeloperoxidase (MPO) activity levels were measured using a peroxidase-based assay to assess granulocyte infiltration as described previously (McCafferty et al., 1997; Riazi et al., 2008). Briefly, colonic tissue was frozen, and all tissues in a series were subsequently assayed concurrently in triplicate as follows: tissue $(50 \mathrm{mg} / \mathrm{ml}$ hexadecyltrimethylammonium bromide buffer) was homogenized and centrifuged, and the supernatant $(7 \mu l)$ reacted with $1 \%$ hydrogen peroxide in a potassium phosphate buffer ( $\mathrm{pH}$ 6.0). Absorbance was measured at $450 \mathrm{~nm}$. All TNBS-treated animals had colonic ulceration and diarrhea, and colon tissue contained high levels of MPO activity, features that were largely absent from the control animals. In some animals, we inhibited microglial activation by intraperitoneal injections of minocycline $(25 \mathrm{mg} / \mathrm{kg}$ every $12 \mathrm{~h}$ dissolved in $0.5 \mathrm{ml}$ of Intralipid) versus vehicle (Intralipid, $0.5 \mathrm{ml} / 12 \mathrm{~h}$ ) for $4 \mathrm{~d}$, beginning on the day of TNBS treatment. Use of Intralipid, a sterile, nonpyrogenic fat emulsion, as a vehicle prevented the pain responses that usually accompany injection of minocycline when it is given in saline. The dose of minocycline was chosen from previous studies (Li et al., 2005; Hua and Walz, 2006). We showed previously that minocycline reduces microglial/macrophage activation after TNBS colitis (Riazi et al., 2008) as well as in other models of neuroinflammation (Galic et al., 2009; D’Mello et al., 2013).
Slice preparation and electrophysiology. Rats were anesthetized with isoflurane and decapitated, and the brains were immediately removed and placed in ice-cold slicing solution $\left(0-4^{\circ} \mathrm{C}\right)$ containing the following (in mM): $87 \mathrm{NaCl}, 2.5 \mathrm{KCl}, 1.25 \mathrm{NaH}_{2} \mathrm{PO}_{4}, 7 \mathrm{MgCl}_{2}, 0.5 \mathrm{CaCl}_{2}, 25$ $\mathrm{NaHCO}_{3}, 25$ glucose, and 75 sucrose. Horizontal hippocampal slices were cut on a vibratome at $400 \mu \mathrm{m}$ thickness for field-potential recording experiments and $300 \mu \mathrm{m}$ for patch-clamp experiments. The slices were immediately transferred to a submerged chamber containing warm $\left(32^{\circ} \mathrm{C}\right)$ artificial CSF [aCSF; containing (in mM) $126 \mathrm{NaCl}, 2.5 \mathrm{KCl}, 1.2$ $\mathrm{NaH}_{2} \mathrm{PO}_{4}, 1.2 \mathrm{MgCl}_{2}, 2.4 \mathrm{CaCl}_{2}, 18 \mathrm{NaHCO}_{3}, 11$ glucose], kept for $1 \mathrm{~h}$ and then maintained at room temperature for at least an additional hour, before recording. Both slicing and aCSF solutions were continuously bubbled with a gas mixture of $5 \% \mathrm{CO}_{2} / 95 \% \mathrm{O}_{2}$ to maintain a $\mathrm{pH}$ of 7.4 .

All recordings were obtained at $30-32^{\circ} \mathrm{C}$ in a submerged chamber with a flow rate of $2-3 \mathrm{ml} / \mathrm{min}$ aCSF. Extracellular field potentials were recorded with glass micropipettes filled with aCSF (3-6 M $\Omega$ ), and signals were acquired using an Axopatch 200A amplifier (Molecular Devices; low-pass filter, $5 \mathrm{kHz}$; high-pass filter, $1 \mathrm{~Hz}$; acquisition frequency, 10 $\mathrm{kHz}$; gain, 500×) and collected using pClamp 9.0 (Molecular Devices). Evoked field EPSPs (fEPSPs) were elicited in the ventral CA1 stratum radiatum by electrically stimulating the Schaffer collaterals with a concentric bipolar electrode (Kopf) at 0, 25, 50, 75, and 100\% maximal stimulation intensities. The highest intensity that created no response was considered $0 \%$, and the point at which the fEPSP slope did not increase further with increasing stimulation was taken as $100 \%$ maximal stimulation intensity.

For measurements of synaptic plasticity, hippocampal slices were stimulated every $15 \mathrm{~s}$ at the Schaffer collaterals through a concentric stimulating electrode at 50\% maximum intensity, and the fEPSPs were recorded from the CA1 striatum radiatum. After $15 \mathrm{~min}$ of recording baseline, LTP was induced by applying three high-frequency trains of stimulations at $100 \mathrm{~Hz}$ with $20 \mathrm{~s}$ intervals (Reid et al., 2004), and longterm depression (LTD) was induced by applying 1800 stimulations at 3 $\mathrm{Hz}$ over $10 \mathrm{~min}$ (Kemp et al., 2000). The fEPSPs were recorded for an additional $45 \mathrm{~min}$. The eEPSPs slopes were calculated and normalized to the mean of the baseline (average value from the $15 \mathrm{~min}$ baseline recordings) and presented as percentage of baseline. The average of the final 10 min of the recordings for each slice was calculated and used for comparisons between treatment groups.

Whole-cell patch-clamp recordings in ventral CA1 pyramidal cells were performed in voltage-clamp mode using an Axopatch 200B amplifier (Molecular Devices). The signal was acquired at $10 \mathrm{kHz}$ and low-pass filtered at $5 \mathrm{kHz}$. We used glass micropipettes (3-6 M $\Omega$ ) for patch-clamp recordings. For recording spontaneous miniature EPSCs (mEPSCs), the pipettes were filled with K-gluconate internal solution containing the following (in mM): $108 \mathrm{~K}$-gluconate, $8 \mathrm{Na}$-gluconate, $2 \mathrm{MgCl}_{2}, 8 \mathrm{KCL}, 1$ EGTA, $4 \mathrm{~K}_{2} \mathrm{ATP}$, $0.3 \mathrm{NaGTP}$, and 10 HEPES, with $\mathrm{pH}$ adjusted to 7.2 with $1 \mathrm{M} \mathrm{KOH}$ solution and osmolarity adjusted to $280-290 \mathrm{mOsmol}$. For recording evoked currents, they were filled with Cs-gluconate internal solution containing the following (in $\mathrm{mm}$ ): 108 Cs-gluconate, 5 tetraethylammonium-Cl, $2.8 \mathrm{NaCl}, 20$ HEPES, 0.4 EGTA, 4 MgATP, 0.3 $\mathrm{NaGTP}, 10$ phosphocreatine $\mathrm{Na}_{2}$, and 1 QX-314, with $\mathrm{pH}$ adjusted to 7.2 with $1 \mathrm{M}$ CsOH solution and osmolarity adjusted to $280-290 \mathrm{mOsmol}$. To record AMPA current rectification, spermine tetrahydrochloride $(0.1$ $\mathrm{mm}$ ) was added to the internal solution. For all the patch-clamp experiments, picrotoxin $(100 \mu \mathrm{M})$ was added to the aCSF, and a cut was made at the CA3 and CA1 interface to prevent CA3-generated seizures from propagating to CA1. Other compounds were bath applied as per need. Cells were accepted for analysis if access resistance was $<20 \mathrm{M} \Omega$ and there was $<20 \%$ change throughout the time course of the recording.

Electrophysiological data were analyzed using Clampfit (MDS Analytical Technologies), SPSS (IBM), and Mini Analysis (Synaptosoft).

Hippocampal tissue preparation for semiquantitative PCR and Western blot. Under deep pentobarbital anesthesia, rats were perfused with cold PBS and decapitated, and the brains were quickly removed. For Western blot and quantitative PCR ( $\mathrm{qPCR}$ ) experiments, we used the CA1 area in the hippocampus. Briefly, the brains were mounted on the vibratome in an ice-cold slicing solution, $1 \mathrm{~mm}$ sections were taken, and the CA1 areas were dissected out under microscopic control by hand using a microsur- 
gical blade; all dissections were performed over ice. For measurement of TNF $\alpha$ by ELISA, whole hippocampi from both sides were obtained. The tissue samples were quickly snap frozen in liquid nitrogen and kept at $-80^{\circ} \mathrm{C}$ until later processing.

Semiquantitative PCR for glutamate receptor $m R N A$. In TNBS-treated and saline-treated control animals ( $n=5-6 /$ group), we measured hippocampal mRNA levels of the GluR2 AMPA receptor subunit, using qPCR and validated primers as described previously (Harré et al., 2008; Galic et al., 2009). All data were normalized against the mRNA levels of an endogenous reference gene, glyceraldehyde-3-phosphate dehydrogenase (GAPDH), and expressed relative to saline-treated controls using the $\Delta \Delta \mathrm{C}_{\mathrm{t}}$ method (Livak and Schmittgen, 2001; Schmittgen and Livak, 2008). Data are presented as relative fold change to saline controls.

Western blot. Tissue samples from the CA1 area of hippocampus from the TNBS- and saline-treated animals were homogenized, and total cellular protein was extracted using RIPA lysis buffer with a protease inhibitor cocktail (Roche). Subsequent to tissue processing and separation of proteins, gels were incubated overnight at $4^{\circ} \mathrm{C}$ with a primary antibody against the GluR2 subunit (1:500; NeuroMab, UC Davis) and a second primary antibody against $\beta$-actin (1:30,000; Millipore) as a loading control. These antibodies have been validated previously by the distributor as specific for the protein of interest by standard criteria (Saper and Sawchenko, 2003) and label bands at the appropriate molecular weight (Reid et al., 2013). Membranes were washed and incubated with infrared fluorescent dye-conjugated secondary antibodies against the hosts of the two primary Abs (Thermo Scientific). Protein bands were visualized using a $\mathrm{Li}$-Cor Odyssey dual wavelength far infrared scanner with imaging in the $800 \mathrm{~nm}$ channel for protein of interest and in the $700 \mathrm{~nm}$ channel for $\beta$-actin. The area under the intensity profile curve of a given band was quantified (Quantity One; Bio-Rad), and the ratio of optical density values for the protein of interest and $\beta$-actin was calculated. The optical density ratios for the saline control group were adjusted to have a value of 1.0 , and the ratios for the experimental groups were then normalized to the saline control group.

Hippocampal TNF $\alpha$ measurement. To assess whether chronic administration of minocycline in TNBS-treated rats altered the CNS immune response, we obtained hippocampal tissues from TNBS-treated animals that received either minocycline or vehicle, and measured the level of TNF $\alpha$ using an ELISA kit (Invitrogen), with a lower limit of detection at $<4 \mathrm{pg} / \mathrm{ml}$. The measurements were adjusted according to the protein content and presented as picograms per milligram of protein.

Chemicals. TNBS, minocycline, and picrotoxin were purchased from Sigma. Intralipid was a product of Fresenius Kabi. Tetrodotoxin (TTX) was purchased from Alomone Laboratories. 1-Naphthyl acetyl spermine trihydrochloride (NASPM), Ro 25-6981 maleate, DNQX, DL-APV, spermine tetrahydrochloride, and QX-314 were all purchased from Tocris Bioscience.

Data analysis. Data are presented as mean \pm SEM. Statistical significance was set at $p<0.05$. For paired, parametric data, either paired or unpaired Student's $t$ test was used. In other cases, the specific statistical tests that were used for analysis are indicated in Results. $n$ represents the number of slices or neurons used in each group and is followed by the number of rats per group. For field-potential recordings, one or two slices per animal were recorded, and for patch-clamp recordings, one or two neurons per animal were recorded.

\section{Results \\ Peripheral inflammation enhances synaptic transmission in hippocampus}

To test the strength of glutamatergic synaptic transmission, we recorded evoked field-potentials from the CA1 area in hippocampal slices of rats treated $4 \mathrm{~d}$ earlier with saline or TNBS. Analyzing the fEPSPs from the TNBS-treated ( $n=8$ slices, 5 rats) versus control animals ( $n=10$ slices, 6 rats) in response to different stimulation intensities (excluding 0\%) using a two-way ANOVA showed that the fEPSP slopes were significantly different between the treatment groups (stimulation intensity $\times$ treatment, $\left.F_{(3,64)}=3.415 ; p=0.023\right)$. Post hoc analyses (Tukey's HSD test) determined that there were significant enhancements in the
TNBS-treated animals at 75\% $(p=0.025)$ and $100 \%(p=$ 0.0007 ) maximum stimulation (Fig. $1 A, B$ ). Moreover, we compared the correlation coefficients $(r)$ of the presynaptic fiber volley amplitude and fEPSP slopes in TNBS-treated animals $(r=$ $0.602, n=32)$ and their controls $(r=0.857, n=32)$ using the Fisher $r$-to- $z$ transformation test, which showed a significant difference $(Z=2.23, p=0.026$; Fig. $1 C)$. This indicates that there was a stronger synaptic response in TNBS-treated animals, even when numbers of afferent fibers stimulated were the same. This change was not due to activation of new non-AMPA receptors, as the enhanced fEPSP was still entirely abolished by the AMPA receptor antagonist DNQX (data not shown). To test whether this enhancement in synaptic transmission was a result of enhanced presynaptic release by the Schaffer collaterals or an augmented postsynaptic response of the CA1 pyramidal cell, we measured the paired-pulse ratio (PPR; the ratio of two fEPSP slopes evoked by two stimulations at 50\% maximum intensity, 50 ms apart), a form of short-term plasticity that is a determinant of presynaptic probability of release (Zucker and Regehr, 2002). Statistical analysis showed no significant difference between the two treatment groups $(1.32 \pm 0.03, n=10$ slices, 6 rats vs $1.30 \pm$ $0.04, n=8$ slices, 5 rats; $t=0.326, p=0.749$; Figure $1 B$, inset bar graph), which suggests a postsynaptic, rather than presynaptic enhancement of synaptic transmission. We subsequently asked whether the enhanced synaptic transmission due to the colitis was long lasting. Thus, we compared the fEPSP stimulus response curves in the treatment animals $10 \mathrm{~d}$ after the induction of inflammation, which is a time point when the acute inflammatory conditions in the gut have substantially resolved (Miampamba et al., 1998; Riazi et al., 2008). There was no difference between the TNBS ( $n=9$ slices, 5 rats) and control groups ( $n=8$ slices, 5 rats) at that time point, indicating that these changes in synaptic transmission resolve when the inflammation subsides (two-way ANOVA, stimulation intensity $\times$ treatment, $F_{(3,60)}=0.175 ; p=0.913$; Fig. $\left.1 D\right)$.

To further study the alteration in excitatory synaptic transmission in the CA1 pyramidal neurons following peripheral inflammation, we used whole-cell recording and measured the relative contribution of AMPA and NMDA receptors to eEPSCs. The AMPA/NMDA ratio has proven to be a sensitive variable for detecting differences in composition of glutamatergic receptors to synaptic potentials (Ungless et al., 2001; Bellone and Lüscher, 2006; Clem and Barth, 2006; Kourrich et al., 2007; Chang et al., 2013). The AMPA receptor-mediated currents were evoked by electrical stimulation of the presynaptic Schaffer collateral fibers at $0.2 \mathrm{~Hz}$ while the neuron was voltage clamped at $-70 \mathrm{mV}$. The stimulation intensity was chosen to induce an AMPA current with a peak amplitude of $\sim 400 \mathrm{pA}$. To record NMDA-mediated eEPSCs, DNQX $(10 \mu \mathrm{M})$ was then added to the bath, and when the AMPAmediated currents completely vanished, the holding voltage was switched to $+40 \mathrm{mV}$. An average of at least 10 traces was used for each current, and the peak amplitude of each current was used to calculate the ratio. Statistical analysis showed a significant decrease in the AMPA/NMDA ratio in TNBS-treated compared with salinetreated animals $(3.28 \pm 0.18, n=15$ cells, 10 rats vs $4.32 \pm 0.17, n=$ 16 cells, 10 rats; $t=4.093, p=0.0003$; Fig. $1 E, F)$. Therefore, there is a relative increase during inflammation in NMDA receptormediated current relative to AMPA receptor-mediated current.

\section{Changes in NMDA-receptor currents in CA1 neurons following peripheral inflammation: reduction in NR2B subunit}

It is possible that, under inflammatory conditions, in addition to glutamate release, there is increased synaptic release of an 
A

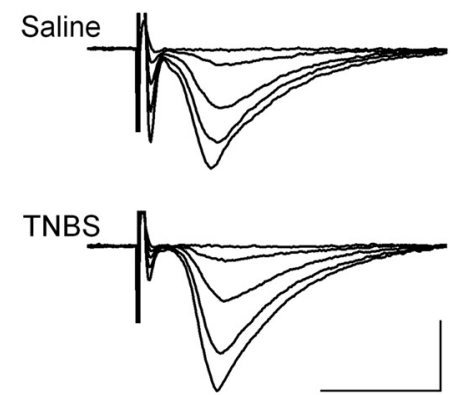

B

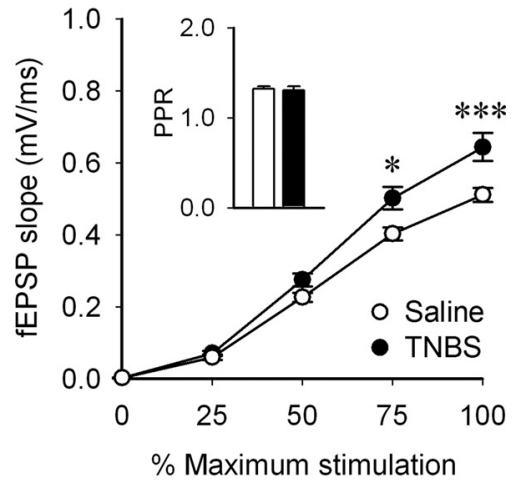

C

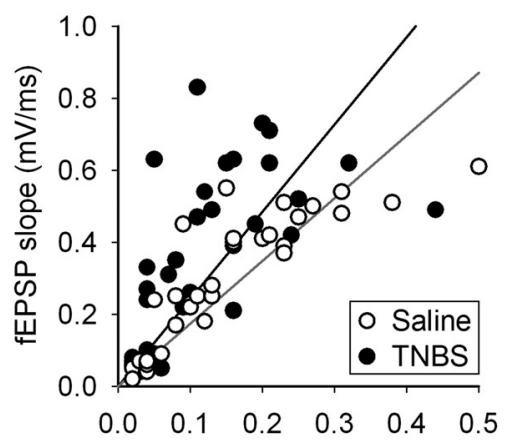

Fiber volley amplitude $(\mathrm{mV})$

E

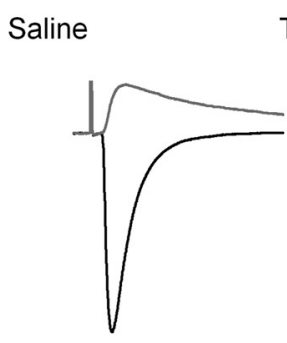

TNBS

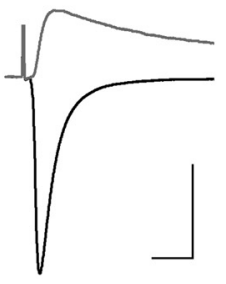

D

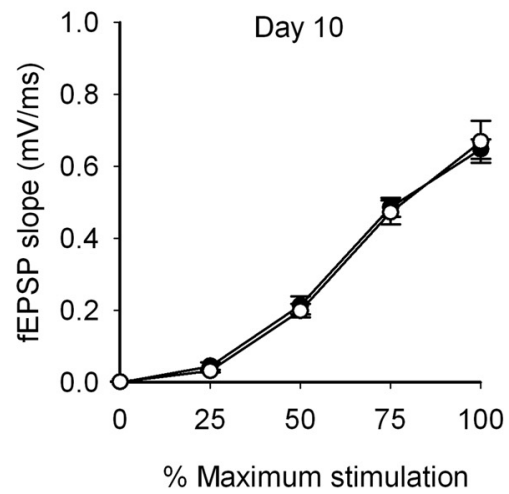

$\mathbf{F}$

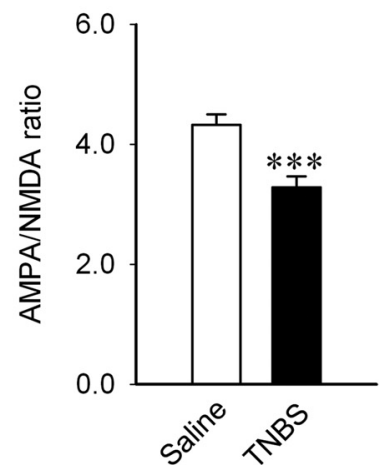

Figure 1. Enhanced synaptic transmission in hippocampus following peripheral inflammation. $\boldsymbol{A}$, Representative fEPSP traces from stimulation of Schaffer collateral, recorded from the CA1 area of hippocampus from TNBS- and saline-treated rats at day 4 after the induction of bowel inflammation by TNBS. Each trace represents the average of five traces. $\boldsymbol{B}$, fEPSPs are significantly enhanced in TNBS-treated rats (saline, $n=10$ slices, 6 rats; TNBS, $n=8$ slices, 5 rats). Data are presented as mean \pm SEM. ${ }^{*} p=$ $0.025 ;{ }^{* * *} p=0.0007$ (two-way ANOVA followed by Tukey's HSD test). The inset represents the PPR, which showed no difference between the two groups (white bars, saline, $n=10$ slices, 6 rats; black bars, TNBS, $n=8$ slices, 5 rats; $t$ test, $p=0.749$ ). $\boldsymbol{C}$, Comparison of the correlation between the size of fEPSP and the fiber volley amplitude between the animals that received TNBS versus controls shows a significant difference (gray line, saline; black line, TNBS; $n=32$ per group; Fisher $r$-to- $z$ transformation test; $p=0.026$ ). $\boldsymbol{D}$, The enhanced fEPSPs are back to control levels at day 10 after TNBS treatment. $\boldsymbol{E}$, Sample traces of AMPA/NMDA ratios measured from the CA1 pyramidal neurons at day 4 after TNBS or saline treatment. AMPA currents (black) were recorded at $-70 \mathrm{mV}$ and NMDA currents (gray) at $+40 \mathrm{mV}$. $\boldsymbol{F}$, The AMPA/NMDA ratios show a significant decrease in TNBS-treated rats (saline, $n=16$ cells, 10 rats; TNBS, $n=15$ cells, 10 rats). Data are presented as mean \pm SEM. ${ }^{* * *} p=0.0003$ ( $t$ test). Calibrations: A, $20 \mathrm{~ms}, 1 \mathrm{mV} ; \boldsymbol{E}, 20 \mathrm{~ms}, 200 \mathrm{pA}$.

NMDA-specific agonist such as quinolinic acid (for review, see Walker et al., 2014) that would preferentially activate NMDA receptors, thus enhancing NMDA receptor activation over glutamate-only AMPA receptor activation. However, when we evaluated the PPR of the NMDA receptor-mediated current only, it was unchanged (control, $1.68 \pm 0.10, n=5$ cells, 4 rats vs
TNBS, $1.70 \pm 0.15, n=4$ cells, 4 rats; $t=$ $-0.117, p=0.910)$. Thus, there is no evidence of additional release of an NMDAspecific ligand in colitis.

One way in which the NMDA component may be altered is through differential expression of receptor subunits with different current carrying capacities. Thus, we asked if there was a change in an NMDA receptor subunit that may underlie changes in NMDA-mediated synaptic responses. We focused on the NR2B subunit, because previous studies have reported that it is altered in various areas of the CNS by peripheral inflammation (Caudle et al., 2005; Wu et al., 2005; Vikman et al., 2008) and in dorsal root ganglion cells by colitis (Li et al., 2006), so we compared the effectiveness of Ro 256981, an NR2B specific antagonist, on the NMDA-mediated currents in CA1 pyramidal neurons from colitic and control rats. The neurons were held at $+40 \mathrm{mV}$ in the presence of DNQX $(10 \mu \mathrm{M})$. The peak amplitudes of the currents before and after the Ro 25-6981 (5 $\mu \mathrm{M}$, a supramaximal dose; Fischer et al., 1997; Lynch et al., 2001) was added to the bath were measured, and a percentage decline in the current amplitude by the antagonist was calculated. The experiment showed that in TNBS-treated animals, Ro 25-6981 reduced the amplitude of the NMDAmediated eEPSCs significantly less in colitic animals than in control animals (control, $43.47 \pm 2.24, n=10$ cells, 6 rats vs TNBS, $33.04 \pm 1.67, n=9$ cells, 6 rats; $t=3.664, p=0.0019)$. Thus, there is a relative decrease in the proportion of postsynaptic NR2B-containing NMDA receptors following TNBS-induced peripheral inflammation (Fig. $2 A, B$ ).

\section{Postsynaptic increase in AMPA currents following peripheral inflammation in hippocampus CA1: increased contribution of $\mathrm{Ca}^{2+}$ permeable AMPA receptors} Since fEPSPs are mediated exclusively by postsynaptic glutamatergic receptor channels, and more specifically by AMPA receptors, we hypothesized that the increase in fEPSPs might result from an increase in postsynaptic AMPA currents. Therefore, in CA1 pyramidal neurons, we recorded mEPSCs using whole-cell patch-clamp recording. With the bath containing picrotoxin $(100 \mu \mathrm{M})$ and TTX $(1 \mu \mathrm{M})$, cells were held at $-70 \mathrm{mV}$, and $\mathrm{mEPSCs}$ were recorded. Analysis indicated no significant difference in mEPSC frequency $(t=-0.904, p=0.382)$, but the mean amplitude of the mEPSCs was significantly higher in TNBS-treated animals (controls, $18.55 \pm 0.97 \mathrm{pA}, n=8$ cells, 
5 rats vs TNBS, $21.76 \pm 1.09 \mathrm{pA}, n=7$ cells, 5 rats; $t=-2.209, p=0.046$; Fig. $3)$. This suggests an increase in postsynaptic AMPA receptors, their current carrying capacity, or both.

Previously we observed an increase in hippocampal TNF $\alpha$ during colitis (Riazi et al., 2008), and a number of studies have reported that this cytokine causes increased expression of GluR2-lacking AMPA receptors (Beattie et al., 2002; Stellwagen and Malenka, 2006). Thus, we asked whether the increase in AMPA currents was due to the insertion of additional GluR2-lacking AMPA receptors. AMPA receptors that contain the GluR2 subunit are impermeable to $\mathrm{Ca}^{2+}$, whereas GluR2-lacking receptors are permeable to $\mathrm{Ca}^{2+}$. When GluR2-lacking subunits are present and in the presence of intracellular spermine, the $I-V$ curve exhibits inward rectification due to block by intracellular polyamines at depolarized potentials (Bowie and Mayer, 1995; Shepherd and Huganir, 2007). To isolate AMPA mediated eEPSCs, picrotoxin $(100 \mu \mathrm{M})$ and APV $(50 \mu \mathrm{M})$ were added to the bath, and spermine $(0.1 \mathrm{~mm})$ was included in the internal solution. Synaptic currents were evoked by electrical stimulation of the presynaptic Schaffer collateral fibers while the pyramidal neurons were held at -60 $\mathrm{mV}$. The stimulation intensity was set at a level to induce a $\sim 400 \mathrm{pA}$ eEPSC. While we stimulated at a rate of $0.2 \mathrm{~Hz}$, the holding potential was changed in $20 \mathrm{mV}$ steps between -60 and $+60 \mathrm{mV}$. For each holding potential, five eEPSCs were averaged. The amplitudes of eEPSCs were calculated and normalized to the amplitude of eEPSCs at $-60 \mathrm{mV}$ (Fig. $4 A, B$ ). A rectification index (RI) was defined by dividing the absolute amplitude of the eEPSC at $+40 \mathrm{mV}$ to that at $-60 \mathrm{mV}$. We observed a significant decrease in the RI in TNBS-treated animals compared with controls $(t=3.343, p=$ 0.004; Fig. $4 C$ ), indicating a higher contribution of GluR2-lacking AMPA receptors. To further confirm this finding, we assessed the ability of a specific GluR2-lacking AMPA receptor antagonist (NASPM, $100 \mu \mathrm{M}$, a dose found previously to be effective; Tsubokawa et al., 1995; Purgianto et al., 2013; Lee et al., 2014) to inhibit the AMPA-mediated eEPSCs. The eEPSCs were recorded at -60 $\mathrm{mV}$ before and after bath application of NASPM. The effect of NASPM was calculated as the percentage decline in the current, which represented the portion of currents mediated by GluR2-lacking receptors. NASPM caused a significantly greater decrease in eEPSC amplitude in TNBS-treated animals compared with controls (control, $12.1 \pm 3.3$ vs TNBS, $30.6 \pm 3.7$; ${ }^{* *} p=0.0019$ ( $t$ test).
A

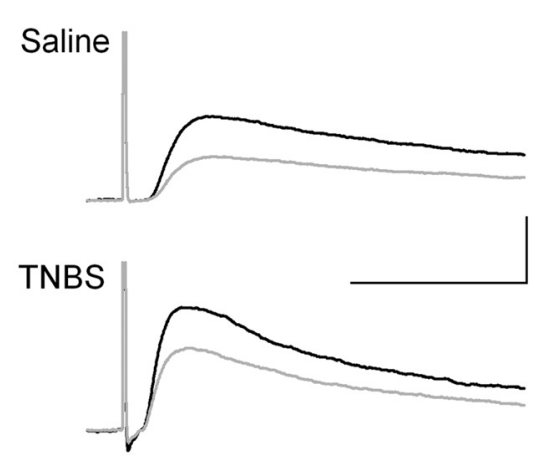

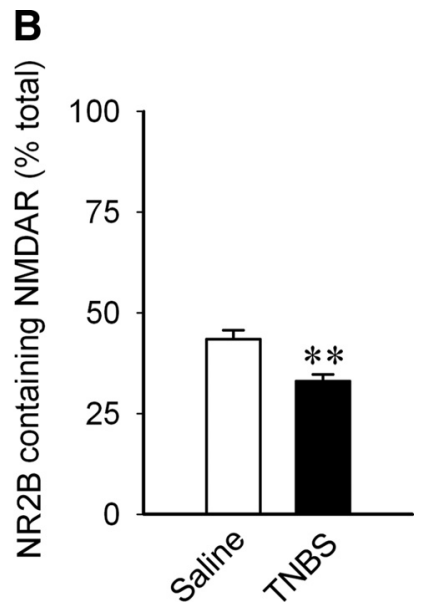

Figure 2. Reduction in NR2B-containing NMDA receptors in pyramidal neurons of the CA1 area during peripheral inflammation. $A$, Sample traces of EPSCs from stimulation of Schaffer collateral, recorded from the CA1 area of hippocampus before (black) and after (gray) the perfusion of NR2B antagonist Ro 25-6981 (5 $\mu \mathrm{m}$ ) and when the effect of the antagonist was stabilized. Currents were recorded at $+40 \mathrm{mV}$, and the peak amplitudes were measured. Each representative trace is an average of at least 10 traces. Calibration: $40 \mathrm{~ms}, 100 \mathrm{pA}$. B, The effect of Ro 25-6981 was calculated as a percentage decline in the current, which represented the portion of currents mediated by NR2B-containing NMDA receptors. In TNBS-treated animals, Ro 25-6981 was less effective in significantly reducing the amplitude of the NMDA-mediated eEPSCs than in control animals (saline, $n=10$ cells, 6 rats; TNBS, $n=$ 9 cells, 6 rats). Data represent the percentage decrease in the size of the initial current amplitude and are shown as mean \pm SEM.
A

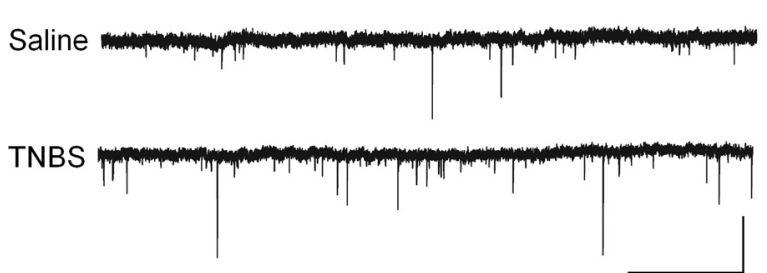

C
B

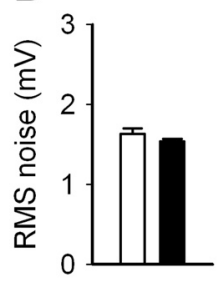

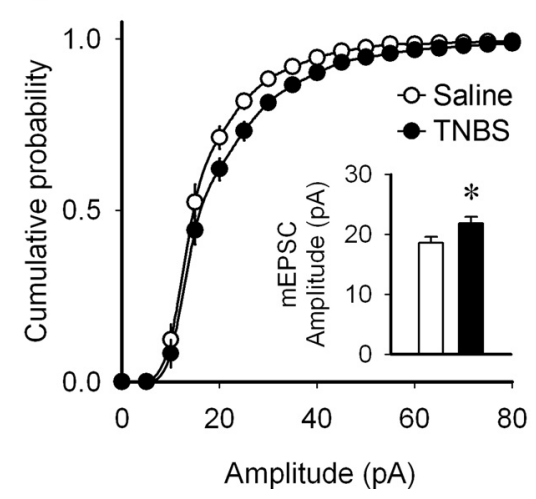

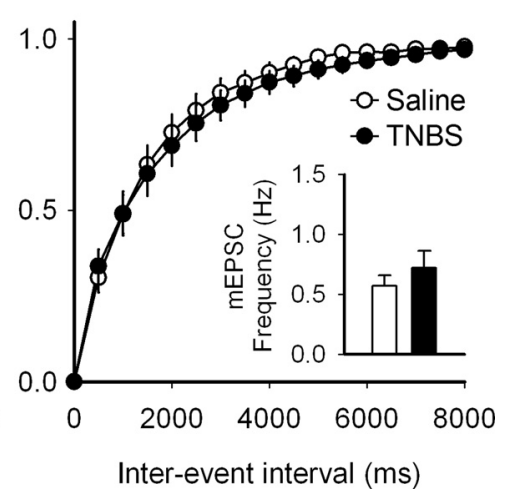

Figure 3. Increased amplitude but not frequency of AMPA mEPSCs in pyramidal neurons of the CA1 area during peripheral inflammation. $A$, Sample voltage-clamp mEPSC recordings from TNBS- and saline-treated rats, $4 \mathrm{~d}$ after the induction of peripheral inflammation. Calibration: $5 \mathrm{~s}, 50 \mathrm{pA}$. B, No significant difference was observed in the noise level from the recordings from the two treatment groups. Data are presented as mean \pm SEM of the root mean square (RMS; white bars, saline; black bars, TNBS; $t$ test, $p=0.180$. C, Cumulative probability graphs from the neurons from saline- and TNBS-treated animals. There was a significant increase the amplitude of the mEPSCs in TNBS-treated animals (left inset bar graph). Data are presented as mean \pm SEM. ${ }^{*} p=$ 0.046 ( $t$ test). No difference was detected in the mEPSC frequency between the two groups (right inset bar graph; $t$ test, $p=0.382$; saline, $n=8$ cells, 5 rats; TNBS, $n=7$ cells, 5 rats).

$t=-3.709 ; p=0.0026)$, consistent with an increased contribution of GluR2-lacking AMPA receptors (Fig. 4D,E). To determine whether colitis decreased the synthesis of GluR2 subunits, we measured both gene expression and protein for GluR2 subunits in area CA1 
A

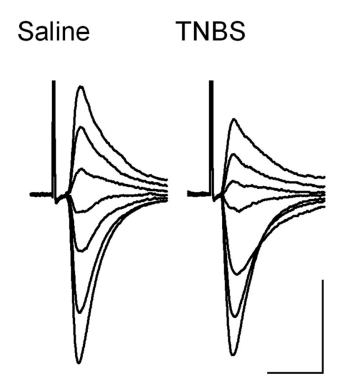

D

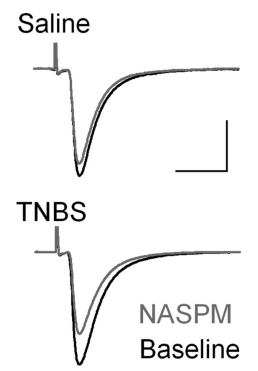

B

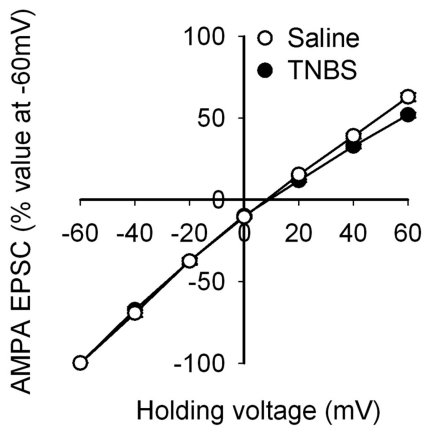

Holding voltage $(\mathrm{mV})$

F

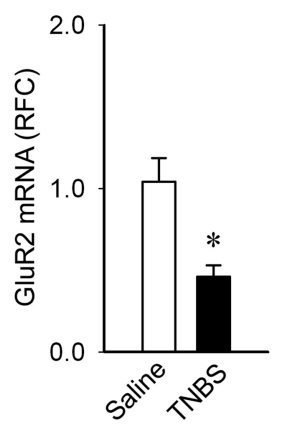

C

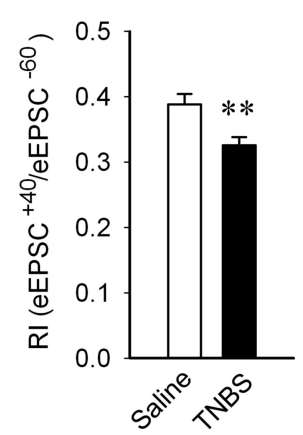

G

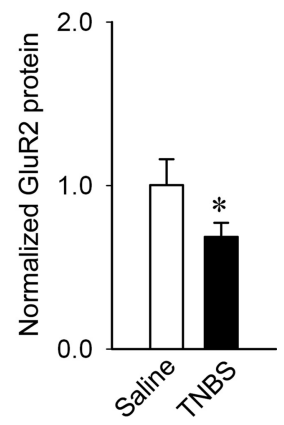

10 , when the inflammation had subsided (Fig. $5 B$; TNBS, $n=5$ slices, 5 rats; saline, $n=5$ slices, 5 rats; $t=0.401, p=0.699$ ). To determine whether this reflected an absolute inability to evoke control-level LTP or whether it was due a requirement for a stronger stimulation to evoke LTP, in slices from an additional series of inflamed animals $(n=5)$, we ran the LTP induction protocol repetitively at $15 \mathrm{~min}$ intervals. The first LTP stimulation elicited the expected low level of LTP $(140 \%$ of control). The two subsequent LTP stimulation protocols did not significantly increase the eEPSP (second stimulus, 153\%; third stimulus, $157 \%$ ), indicating that the threshold to evoke LTP had not changed, but rather there was an inability to sustain LTP in the inflamed animals. LTD was evoked with 1800 stimuli delivered at $3 \mathrm{~Hz}$ over $10 \mathrm{~min}$. This was also significantly decreased in animals that received TNBS treatment compared with controls (Fig. $5 C$; TNBS, $n=9$ slices, 7 rats; saline, $n=9$ slices, 7 rats; $t=-2.225$, $p=0.04)$.

Figure 4. Peripheral inflammation induces the insertion of GluR2-lacking AMPA receptors to the synapse. A, Sample EPSC recordings of stimulation of the Schaffer collateral at different holding potentials $(-60$ to $+60 \mathrm{mV})$ from the pyramidal neurons in the CA1 area of hippocampus from saline- and TNBS-treated rats at day 4 after the induction of bowel inflammation by TNBS. Each trace represents the average of five traces. $B, C$, Significant AMPA current rectification is observed in TNBS-treated neurons (saline, $n=11$ cells, 7 rats; TNBS, $n=13$ cells, 7 rats). The RI (defined as the ratio of eEPSC amplitude at $+40 \mathrm{mV}$ to that at $-60 \mathrm{mV}$ ) was significantly decreased in neurons from TNBS-treated animals. Data are presented as mean \pm SEM. ${ }^{* *} p=0.0044$ ( $t$ test). D, Sample traces of evoked EPSCs from stimulation of the Schaffer collateral, recorded from the CA1 area of hippocampus before (black) and after (gray) the perfusion of the GluR2-lacking AMPA receptor antagonist NASPM (100 $\mu \mathrm{M})$. Currents were recorded at $-60 \mathrm{mV}$, and the peak amplitudes were measured. Each representative trace is an average of at least 10 traces. $\boldsymbol{E}$, The effect of NASPM was calculated and presented as the percentage decline in the current. A significant increase was observed in the effect of NASPM in TNBS-treated rats compared to controls that would translate into increased postsynaptic insertion of the GluR2-lacking AMPA receptor in TNBS-treated animals. Data represent the mean \pm SEM (saline, $n=7$ cells, 4 rats; TNBS, $n=8$ cells, 4 rats). ${ }^{* *} p=0.0026$ ( $t$ test). $\boldsymbol{F}$, There were decreased mRNA levels of the GluR2 subunit in the CA1 area of hippocampus in the animals with peripheral inflammation compared with controls (saline, $n=5 ;$ TNBS, $n=5 ; t$ test $, t=3.6547,{ }^{*} p=0.0065$ ). $G$, There was significantly less GluR2 protein expression in the CA1 area of hippocampus in the animals with peripheral inflammation compared to controls (Mann-Whitney $U$ test, $z=-2.008,{ }^{*} p=0.045 ;$ saline, $n=5 ; \mathrm{TNBS}, n=6$ ). Calibrations: $A, D, 20 \mathrm{~ms}$, $200 \mathrm{pA}$.

area using semiquantitative PCR and Western blots. We observed both decreased expression of mRNA $(t=3.6547, p=0.0065)$ and synthesis (Mann-Whitney $U$ test, $z=-2.008, p=0.045)$ of this subunit protein (Fig. $4 F, G$ ).

\section{Decreased synaptic plasticity in hippocampal CA1 area following peripheral inflammation}

Because changes in glutamate receptor subunit expression alter ability to support LTP (Collingridge et al., 2004; Emond et al., 2010; Foster et al., 2010), we hypothesized that synaptic plasticity may be altered in colitis. Therefore, we performed field-potential recordings from CA1 area in hippocampus to study LTP and LTD. LTP was elicited with three $1 \mathrm{~s}, 100 \mathrm{~Hz}$ stimuli at $20 \mathrm{~s}$ intervals applied through a concentric stimulating electrode placed on the Schaffer collateral pathway, and fEPSPs were recorded in stratum radiatum. There was a significant decrease in the level of LTP at day 4 in TNBS-treated animals compared to saline-treated controls (Fig. $5 A$; TNBS, $n=8$ slices, 5 rats; saline, $n=6$ slices, 4 rats; $t=3.275, p=0.007$ ), which recovered at day

\section{Minocycline inhibits the changes in synaptic transmission and plasticity following peripheral inflammation}

We showed previously that the changes in brain excitability, revealed through decreased seizure thresholds in TNBS colitis, are mediated through activation of microglia in the brain (Riazi et al., 2008). Here, we asked whether the changes in synaptic transmission and plasticity observed in hippocampus during peripheral inflammation were also mediated by activation of microglia/macrophages. To test this, we treated two groups of TNBS-treated animals, one with minocycline and the other with vehicle, and on day 4 performed fieldpotential recordings to test evoked synaptic responses, LTP, and LTD in the two groups. Whereas minocycline had no effect on the severity of colitis, either on macroscopic bowel inflammation scores or on MPO activity values (Fig. 6A), minocycline significantly decreased $\mathrm{TNF} \alpha$ levels in the hippocampus of TNBS-treated animals (Fig. $6 B ; n=8, t=4.289$, $p=0.0007$ ). Furthermore, the enhancement of fEPSPs (Fig. $6 C ; n=7-10$ each; two-way ANOVA, stimulation intensity $\times$ treatment, $F_{(9,108)}=2.061 ; p=0.039$, excluding $0 \%$ stimulation intensity values) and the decrease in the levels of LTP (Fig. $6 D$; one-way ANOVA, $F_{(3,25)}=14.42, p=0.000012$ ) that was observed with TNBS treatment were also prevented by minocycline treatments. Likewise, minocycline significantly reversed the reduced LTD seen in TNBS colitis (Fig. 6E; $t=-2.349, p=0.047)$. These experiments indicate that microglial/macrophage activation plays an important role in the hippocampal synaptic changes following peripheral inflammation. 


\section{Discussion}

We have shown that intestinal inflammation is associated with a reversible alteration of excitatory synaptic properties in CA1 hippocampus. We observed a striking increase in the amplitude of AMPAmediated fEPSPs in animals with colitis, associated with an increase in the proportion of membrane receptors lacking the GluR2 subunit. In addition, NMDAmediated transmission was increased in CA1 pyramidal neurons, associated with a relative decrease in NR2B-containing subunits. During inflammation, both LTP and LTD were diminished, and both the decreased plasticity and the increase in basal synaptic transmission were reversed by minocycline, an inhibitor of microglial/macrophage activation.

The increase in AMPA-mediated excitatory transmission could be due to inflammation-induced changes in the release or availability of glutamate. This appears unlikely, because there was neither a change in the afferent volley to postsynaptic potential ratio, nor in the PPR of either the AMPA- or the NMDA-mediated potentials. In addition, the similar frequencies of mEPSCs in inflamed and control slices is inconsistent with increased glutamate release or reduced reuptake. It is interesting that a number of behavioral stressors (Hill et al., 2005; Crosby et al., 2011) as well as peripheral inflammation (Hu et al., 2012) downregulate cannabinoid $\mathrm{CB}_{1}$ receptors, leading to increased transmitter release; however, it is unlikely that the downregulation of $\mathrm{CB}_{1}$ receptors on Schaffer collateral presynaptic terminals occurred after colitis because there was no change in PPR. Our results do, however, suggest alteration in postsynaptic receptors. As the increased fEPSP seen during inflammation was most evident at higher stimulus strengths, we considered that the strong depolarization could be recruiting other receptor populations, in particular, NMDA receptors. This is a strong possibility, as it has been reported that peripheral inflammation using Freund's Complete Adjuvant in the hind paw in rat causes a shift in the hyperpolarizing direction of NMDA receptor activation in the dorsal horn (Guo and Huang, 2001). However, we found that the enhanced fEPSP observed during inflammation was completely blocked by an AMPA receptor antagonist. Thus, if NMDA receptors were to be activated at a lower threshold, it is not close enough to the resting potential to be activated by the Schaffer collateral stimulation.

Nonetheless, it does appear that NMDA receptors are also altered in the setting of peripheral inflammatory disease. Our

A

B
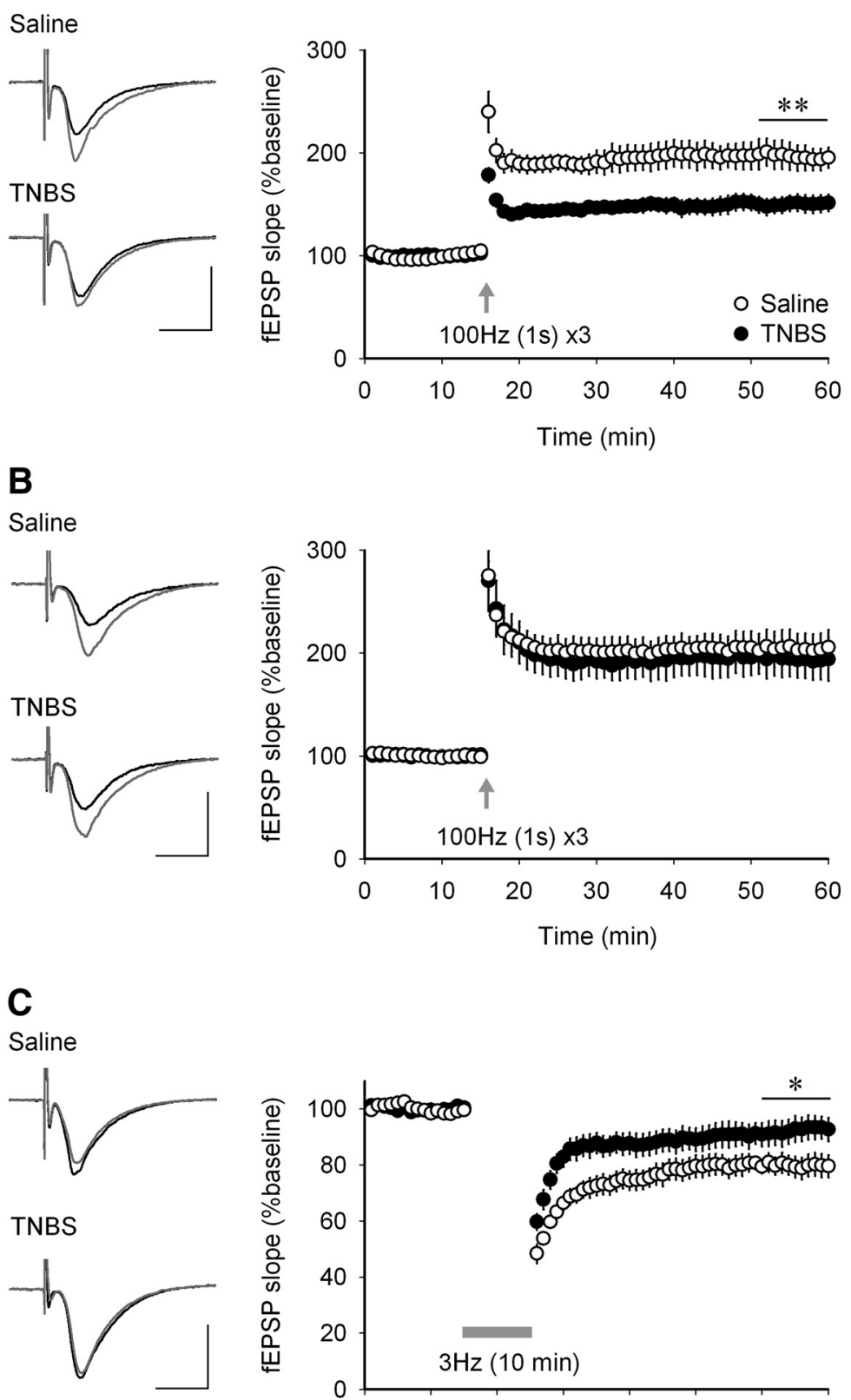

Time $(\min )$

Figure 5. Peripheral inflammation is associated with a reduction in hippocampal synaptic long-term plasticity. $\boldsymbol{A}$, Sample traces of fEPSPs are presented on the left, before (black) and after (gray) high-frequency stimulation (three $1 \mathrm{~s}, 100 \mathrm{~Hz}$ stimuli at $20 \mathrm{~s}$ intervals), and each is an average of 5-10 traces. $0 \mathrm{n}$ the right, grouped data are presented, normalized to baseline EPSP slope. There was decreased ability to induce LTP $4 \mathrm{~d}$ following TNBS treatment (saline, $n=6$ slices, 4 rats; TNBS, $n=8$ slices, 5 rats). ${ }^{* *} p=0.007$ ( $t$ test). $\boldsymbol{B}$, No difference was observed in the LTP levels at $10 \mathrm{~d}$ after inflammation, indicating the reversibility of such a phenomenon (saline, $n=5$ slices, 5 rats; TNBS, $n=5$ slices, 5 rats; $p=0.699, t$ test). C, Induction of LTD by low-frequency stimulation ( 1800 stimulations at $3 \mathrm{~Hz}$ ) was also decreased in TNBS-treated animals compared with saline controls at $4 \mathrm{~d}$ after treatment (saline, $n=9$ slices, 7 rats; TNBS, $n=9$ slices, 7 rats). ${ }^{*} p=0.04$ ( $t$ test). Calibrations: $10 \mathrm{~ms}, 0.5 \mathrm{mV}$.

AMPA/NMDA ratio study indicated that there was a relative increase in the NMDA component of the synaptic current. Although this could occur if either AMPA currents were reduced or if NMDA currents were increased, our observation that AMPA currents were actually increased indicates that there is a particularly dramatic increase in the NMDA current to cause this ratio to 
A

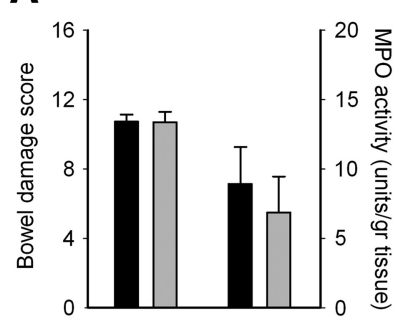

B

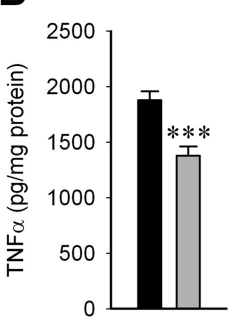

C

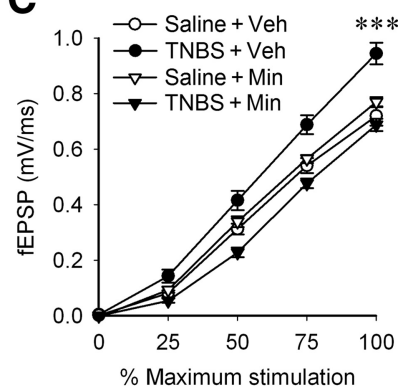

The lack of changes in AMPA-mediated mEPSC frequency would argue against the emergence of previously silent synapses (Shi et al., 1999; for review, see Hanse et al., 2013), although we cannot eliminate the possibility that receptors underlying mEPSCs are not identical to those activated by evoked transmitter release. The increased AMPA receptor-mediated transmission could be due to increased conductance at AMPA receptors, because mEPSCs displayed increased amplitude. It is well accepted that AMPA receptors are highly dynamic, cycling in and out of the membrane, thus providing opportunity for insertion of receptors that have different subunit compositions (for review, see Shepherd and Huganir, 2007). Furthermore, different subunit compositions endow AMPA receptors with different current passing abilities. The GluR2 subunit is particularly important in this regard, because it blocks calcium entry (Hollmann et al., 1991). Our data demonstrating increased rectification of AMPA currents at positive membrane potentials as well as the increased efficacy of an antagonist directed at GluR2-lacking AMPA receptors indicate that inflammation is associated with increased contribution of GluR2lacking AMPA receptors to synaptic transmission. This finding is in keeping with the increased AMPA mEPSC amplitudes, as GluR2-lacking receptors pass more current (Hollmann et al., 1991; Thiagarajan et al., 2005). A similar switch to GluR2-lacking AMPA receptors has also been reported in the dorsal horn during change as it did. We considered that possibility that this could be due to release of an NMDA-specific agonist such as quinolinic acid, known to be synthesized in inflammation-induced depression (for review, see Dantzer et al., 2008). Although we found no evidence for this, our finding of increased NMDA function is compatible with observations that NMDA receptor blockade attenuates inflammation-induced depression (Walker et al., 2013).

Furthermore, we also showed that this increase in NMDA current was associated with a decreased effectiveness of an NR2B antagonist to reduce synaptic transmission, indicating a decreased contribution of the NR2B subunit. This accords with previous reports that colitis causes a decreased effectiveness of the NR2B antagonist ifenprodil to inhibit synaptic transmission in dorsal root ganglia ( $\mathrm{Li}$ et al., 2006). However, it is noted that NMDA transmission has been examined in a number of inflammatory models, and the outcomes have been highly variable. For example, NMDA receptors have been reported to be both upregulated (Rygh et al., 2001) and downregulated (Vikman et al., 2008) in spinal cord and upregulated in forebrain (Wu et al., 2005) after localized peripheral inflammation. With brain inflammation brought about by either intracerebroventricular lipopolysaccharide infusion (Ma et al., 2014) or experimental autoimmune encephalomyelitis (Di Filippo et al., 2013), NR2B subunit protein levels were downregulated in hippocampus.

inflammatory pain (Vikman et al., 2008; Park et al., 2014).

There is considerable evidence that subunit composition endows properties upon glutamate receptors that affect their ability to undergo use-dependent plasticity (Sakimura et al., 1995; Jia et al., 1996; for review, see Collingridge et al., 2004; Emond et al., 2010). Thus we evaluated the ability of CA1 synapses to undergo LTP and LTD. Both of these phenomena were significantly reduced in slices taken from inflamed animals. Given the acknowledged roles of NR2B subunits and of GluR2-lacking AMPA subunits in both LTP and LTD (Emond et al., 2010; Foster et al., 2010; Wiltgen et al., 2010; Park et al., 2014) as well as the dependence of both phenomena on intracellular $\mathrm{Ca}^{2+}$, we had anticipated that these forms of synaptic plasticity would be altered. That they were profoundly depressed suggests either that they were already in an altered state before stimulation and were already at a ceiling, or that the reduced NR2B subunits were causal for this. Also likely is the possibility that the chronic inflammation also altered one or more of the many other intracellular kinases and scaffolding proteins required for these plastic events (Sanderson and Dell'Acqua, 2011; Hunt and Castillo, 2012; Nicolas et al., 2013).

We observed previously that enhanced in vivo brain excitability during colitis requires both elevated cytokines (especially $\mathrm{TNF} \alpha$ ) and microglial activation; thus, the increased contribution of GluR2-lacking AMPA receptors is entirely consistent with 
reports of TNF $\alpha$ action to insert GluR2-lacking AMPA receptors in the membrane (Stellwagen et al., 2005; for review, see Pribiag and Stellwagen, 2014). We have also shown that TNF $\alpha$ levels are increased in the hippocampus following peripheral inflammation (Riazi et al., 2008). TNF $\alpha$ in the brain is thought to be produced mostly by microglia (Gosselin and Rivest, 2007); thus we asked whether the observed changes in synaptic transmission were dependent on microglial/macrophage activation. Treatment of animals with the microglia activation inhibitor minocycline effectively reversed both the increased TNF $\alpha$ levels and the altered synaptic transmission and plasticity. Although minocycline may have effects additional to inhibition of microglial cells, we showed previously that, at the doses we use, it inhibits microglia activation arising from peripheral inflammation (Riazi et al., 2008; D'Mello et al., 2013); it is important to note that this occurs without affecting the peripheral colonic inflammation.

Although our results are consistent with an involvement of TNF $\alpha$ in the abrogated synaptic plasticity, other cytokines, such as IL- $1 \beta$, could be involved. For example, IL- $1 \beta$ has been shown to mediate the reduced LTP seen in another model of peripheral inflammation (Lai et al., 2006). It also acutely alters AMPA receptor expression (Lai et al., 2006) and inhibits LTP (Katsuki et al., 1990; Bellinger et al., 1993). However, the roles of the inflammatory cytokines in synaptic plasticity are not yet clear. For example, mice lacking TNF receptor type 1 display full LTP and LTD (Stellwagen and Malenka, 2006), although one study reported impaired LTD, but not LTP (Albensi and Mattson, 2000). The reduction in LTP and LTD during colitis is consistent with reports that various types of peripheral or central inflammation impair synaptic plasticity (Imamura et al., 2011; Liu et al., 2012; Di Filippo et al., 2013; Maggio et al., 2013; Nisticò et al., 2013). It is interesting that nearly all peripheral inflammatory diseases are associated with comorbid behavioral effects ranging from mood disorders to fatigue to cognitive impairments (Dantzer et al., 2008; D'Mello and Swain, 2011; Russell et al., 2011). In animal models of colitis, it is difficult to study behavioral effects, as the pain associated with this condition interferes with movement. Given that both LTP and LTD are likely cellular correlates of learning and memory (for review, see Malenka and Bear, 2004; Takeuchi et al., 2014), our observations of reductions in both of these phenomena during colitis may provide a mechanistic basis for the cognitive dysfunction reported by patients with colitis and other inflammatory diseases.

\section{References}

Albensi BC, Mattson MP (2000) Evidence for the involvement of TNF and NF-kappaB in hippocampal synaptic plasticity. Synapse 35:151-159. Medline

Beattie EC, Stellwagen D, Morishita W, Bresnahan JC, Ha BK, Von Zastrow M, Beattie MS, Malenka RC (2002) Control of synaptic strength by glial TNFalpha. Science 295:2282-2285. CrossRef Medline

Bellinger FP, Madamba S, Siggins GR (1993) Interleukin 1 beta inhibits synaptic strength and long-term potentiation in the rat CA1 hippocampus. Brain Res 628:227-234. CrossRef Medline

Bellone C, Lüscher C (2006) Cocaine triggered AMPA receptor redistribution is reversed in vivo by mGluR-dependent long-term depression. Nat Neurosci 9:636-641. CrossRef Medline

Benson C, Kerr BJ (2014) Pain and cognition in multiple sclerosis. Curr Top Behav Neurosci 20:201-215. CrossRef Medline

Bowie D, Mayer ML (1995) Inward rectification of both AMPA and kainate subtype glutamate receptors generated by polyamine-mediated ion channel block. Neuron 15:453-462. CrossRef Medline

Butterworth RF (2013) The liver-brain axis in liver failure: neuroinflammation and encephalopathy. Nat Rev Gastroenterol Hepatol 10:522-528. CrossRef Medline

Camara ML, Corrigan F, Jaehne EJ, Jawahar MC, Anscomb H, Baune BT
(2015) Effects of centrally administered etanercept on behavior, microglia, and astrocytes in mice following a peripheral immune challenge. Neuropsychopharmacology 40:502-512. CrossRef Medline

Caudle RM, Perez FM, Del Valle-Pinero AY, Iadarola MJ (2005) Spinal cord NR1 serine phosphorylation and NR2B subunit suppression following peripheral inflammation. Mol Pain 1:25. CrossRef Medline

Chang HF, Su CL, Chang CH, Chen YW, Gean PW (2013) The beneficial effects of leptin on REM sleep deprivation-induced cognitive deficits in mice. Learn Mem 20:328-335. CrossRef Medline

Clem RL, Barth A (2006) Pathway-specific trafficking of native AMPARs by in vivo experience. Neuron 49:663-670. CrossRef Medline

Collingridge GL, Isaac JT, Wang YT (2004) Receptor trafficking and synaptic plasticity. Nat Rev Neurosci 5:952-962. CrossRef Medline

Collins LM, Toulouse A, Connor TJ, Nolan YM (2012) Contributions of central and systemic inflammation to the pathophysiology of Parkinson's disease. Neuropharmacology 62:2154-2168. CrossRef Medline

Crosby KM, Inoue W, Pittman QJ, Bains JS (2011) Endocannabinoids gate state-dependent plasticity of synaptic inhibition in feeding circuits. Neuron 71:529-541. CrossRef Medline

Dantzer R, O'Connor JC, Freund GG, Johnson RW, Kelley KW (2008) From inflammation to sickness and depression: when the immune system subjugates the brain. Nat Rev Neurosci 9:46-56. CrossRef Medline

Di Filippo M, Chiasserini D, Gardoni F, Viviani B, Tozzi A, Giampà C, Costa C, Tantucci M, Zianni E, Boraso M, Siliquini S, de Iure A, Ghiglieri V, Colcelli E, Baker D, Sarchielli P, Fusco FR, Di Luca M, Calabresi P (2013) Effects of central and peripheral inflammation on hippocampal synaptic plasticity. Neurobiol Dis 52:229-236. CrossRef Medline

D’Mello C, Swain MG (2011) Liver-brain inflammation axis. Am J Physiol Gastrointest Liver Physiol 301:G749-G761. CrossRef Medline

D’Mello C, Swain MG (2014) Liver-brain interactions in inflammatory liver diseases: implications for fatigue and mood disorders. Brain Behav Immun 35:9-20. CrossRef Medline

D’Mello C, Riazi K, Le T, Stevens KM, Wang A, McKay DM, Pittman QJ, Swain MG (2013) P-selectin-mediated monocyte-cerebral endothelium adhesive interactions link peripheral organ inflammation to sickness behaviors. J Neurosci 33:14878-14888. CrossRef Medline

Emond MR, Montgomery JM, Huggins ML, Hanson JE, Mao L, Huganir RL, Madison DV (2010) AMPA receptor subunits define properties of statedependent synaptic plasticity. J Physiol 588:1929-1946. CrossRef Medline

Ferrari CC, Tarelli R (2011) Parkinson's disease and systemic inflammation. Parkinsons Dis 2011:436813. Medline

Fischer G, Mutel V, Trube G, Malherbe P, Kew JN, Mohacsi E, Heitz MP, Kemp JA (1997) Ro 25-6981, a highly potent and selective blocker of $\mathrm{N}$-methyl-D-aspartate receptors containing the NR2B subunit. Characterization in vitro. J Pharmacol Exp Ther 283:1285-1292. Medline

Foster KA, McLaughlin N, Edbauer D, Phillips M, Bolton A, ConstantinePaton M, Sheng M (2010) Distinct roles of NR2A and NR2B cytoplasmic tails in long-term potentiation. J Neurosci 30:2676-2685. CrossRef Medline

Galic MA, Riazi K, Henderson AK, Tsutsui S, Pittman QJ (2009) Viral-like brain inflammation during development causes increased seizure susceptibility in adult rats. Neurobiol Dis 36:343-351. CrossRef Medline

Galic MA, Riazi K, Pittman QJ (2012) Cytokines and brain excitability. Front Neuroendocrinol 33:116-125. CrossRef Medline

Gosselin D, Rivest S (2007) Role of IL-1 and TNF in the brain: twenty years of progress on a Dr. Jekyll/Mr. Hyde duality of the innate immune system. Brain Behav Immun 21:281-289. CrossRef Medline

Gralnek IM, Hays RD, Kilbourne A, Rosen HR, Keeffe EB, Artinian L, Kim S, Lazarovici D, Jensen DM, Busuttil RW, Martin P (2000) Development and evaluation of the Liver Disease Quality of Life instrument in persons with advanced, chronic liver disease-the LDQOL 1.0. Am J Gastroenterol 95:3552-3565. Medline

Guo H, Huang LY (2001) Alteration in the voltage dependence of NMDA receptor channels in rat dorsal horn neurones following peripheral inflammation. J Physiol 537:115-123. CrossRef Medline

Hanse E, Seth H, Riebe I (2013) AMPA-silent synapses in brain development and pathology. Nat Rev Neurosci 14:839-850. CrossRef Medline

Harré EM, Galic MA, Mouihate A, Noorbakhsh F, Pittman QJ (2008) Neonatal inflammation produces selective behavioural deficits and alters $\mathrm{N}$-methyl-D-aspartate receptor subunit mRNA in the adult rat brain. Eur J Neurosci 27:644-653. CrossRef Medline 
Häuser W, Janke KH, Klump B, Hinz A (2011) Anxiety and depression in patients with inflammatory bowel disease: comparisons with chronic liver disease patients and the general population. Inflamm Bowel Dis 17:621632. CrossRef Medline

Hill MN, Patel S, Carrier EJ, Rademacher DJ, Ormerod BK, Hillard CJ, Gorzalka BB (2005) Downregulation of endocannabinoid signaling in the hippocampus following chronic unpredictable stress. Neuropsychopharmacology 30:508-515. CrossRef Medline

Hollmann M, Hartley M, Heinemann S (1991) Ca2+ permeability of KAAMPA-gated glutamate receptor channels depends on subunit composition. Science 252:851-853. CrossRef Medline

Hu H, Ho W, Mackie K, Pittman QJ, Sharkey KA (2012) Brain CB(1) receptor expression following lipopolysaccharide-induced inflammation. Neuroscience 227:211-222. CrossRef Medline

Hua R, Walz W (2006) Minocycline treatment prevents cavitation in rats after a cortical devascularizing lesion. Brain Res 1090:172-181. CrossRef Medline

Hunt DL, Castillo PE (2012) Synaptic plasticity of NMDA receptors: mechanisms and functional implications. Curr Opin Neurobiol 22:496-508. CrossRef Medline

Imamura $\mathrm{Y}$, Wang $\mathrm{H}$, Matsumoto $\mathrm{N}$, Muroya $\mathrm{T}$, Shimazaki J, Ogura $\mathrm{H}$, Shimazu T (2011) Interleukin-1beta causes long-term potentiation deficiency in a mouse model of septic encephalopathy. Neuroscience 187 : 63-69. CrossRef Medline

Jia Z, Agopyan N, Miu P, Xiong Z, Henderson J, Gerlai R, Taverna FA, Velumian A, MacDonald J, Carlen P, Abramow-Newerly W, Roder J (1996) Enhanced LTP in mice deficient in the AMPA receptor GluR2. Neuron 17:945-956. CrossRef Medline

Katsuki H, Nakai S, Hirai Y, Akaji K, Kiso Y, Satoh M (1990) Interleukin-1 beta inhibits long-term potentiation in the CA3 region of mouse hippocampal slices. Eur J Pharmacol 181:323-326. CrossRef Medline

Kemp N, McQueen J, Faulkes S, Bashir ZI (2000) Different forms of LTD in the CA1 region of the hippocampus: role of age and stimulus protocol. Eur J Neurosci 12:360-366. CrossRef Medline

Kourrich S, Rothwell PE, Klug JR, Thomas MJ (2007) Cocaine experience controls bidirectional synaptic plasticity in the nucleus accumbens. J Neurosci 27:7921-7928. CrossRef Medline

Lai AY, Swayze RD, El-Husseini A, Song C (2006) Interleukin-1 beta modulates AMPA receptor expression and phosphorylation in hippocampal neurons. J Neuroimmunol 175:97-106. CrossRef Medline

Lee H, Brott BK, Kirkby LA, Adelson JD, Cheng S, Feller MB, Datwani A, Shatz CJ (2014) Synapse elimination and learning rules co-regulated by MHC class I H2-Db. Nature 509:195-200. CrossRef Medline

Li J, McRoberts JA, Ennes HS, Trevisani M, Nicoletti P, Mittal Y, Mayer EA (2006) Experimental colitis modulates the functional properties of NMDA receptors in dorsal root ganglia neurons. Am J Physiol Gastrointest Liver Physiol 291:G219-G228. CrossRef Medline

Li WW, Setzu A, Zhao C, Franklin RJ (2005) Minocycline-mediated inhibition of microglia activation impairs oligodendrocyte progenitor cell responses and remyelination in a non-immune model of demyelination. J Neuroimmunol 158:58-66. CrossRef Medline

Liu X, Wu Z, Hayashi Y, Nakanishi H (2012) Age-dependent neuroinflammatory responses and deficits in long-term potentiation in the hippocampus during systemic inflammation. Neuroscience 216:133-142. CrossRef Medline

Livak KJ, Schmittgen TD (2001) Analysis of relative gene expression data using real-time quantitative PCR and the 2(-Delta Delta C(T)) method. Methods 25:402-408. CrossRef Medline

Lynch DR, Shim SS, Seifert KM, Kurapathi S, Mutel V, Gallagher MJ, Guttmann RP (2001) Pharmacological characterization of interactions of RO 25-6981 with the NR2B (epsilon2) subunit. Eur J Pharmacol 416:185195. CrossRef Medline

Ma J, Choi BR, Chung C, Min SS, Jeon WK, Han JS (2014) Chronic brain inflammation causes a reduction in GluN2A and GluN2B subunits of NMDA receptors and an increase in the phosphorylation of mitogenactivated protein kinases in the hippocampus. Mol Brain 7:33. CrossRef Medline

Maggio N, Shavit-Stein E, Dori A, Blatt I, Chapman J (2013) Prolonged systemic inflammation persistently modifies synaptic plasticity in the hippocampus: modulation by the stress hormones. Front Mol Neurosci 6:46. Medline

Maini RN, Breedveld FC, Kalden JR, Smolen JS, Furst D, Weisman MH, St
Clair EW, Keenan GF, van der Heijde D, Marsters PA, Lipsky PE (2004) Sustained improvement over two years in physical function, structural damage, and signs and symptoms among patients with rheumatoid arthritis treated with infliximab and methotrexate. Arthritis Rheum 50: 1051-1065. CrossRef Medline

Malenka RC, Bear MF (2004) LTP and LTD: an embarrassment of riches. Neuron 44:5-21. CrossRef Medline

Mayoux-Benhamou MA (2006) Fatigue and rheumatoid arthritis. Ann Readapt Med Phys 49:301-304, 385-388. CrossRef Medline

McCafferty DM, Wallace JL, Sharkey KA (1997) Effects of chemical sympathectomy and sensory nerve ablation on experimental colitis in the rat. Am J Physiol 272:G272-G280. Medline

Miampamba M, Parr EJ, McCafferty DM, Wallace JL, Sharkey KA (1998) Effect of intracolonic benzalkonium chloride on trinitrobenzene sulphonic acid-induced colitis in the rat. Aliment Pharmacol Ther 12:219228. CrossRef Medline

Nicolas CS, Amici M, Bortolotto ZA, Doherty A, Csaba Z, Fafouri A, Dournaud P, Gressens P, Collingridge GL, Peineau S (2013) The role of JAK-STAT signaling within the CNS. JAKSTAT 2:e22925. Medline

Nisticò R, Mango D, Mandolesi G, Piccinin S, Berretta N, Pignatelli M, Feligioni M, Musella A, Gentile A, Mori F, Bernardi G, Nicoletti F, Mercuri NB, Centonze D (2013) Inflammation subverts hippocampal synaptic plasticity in experimental multiple sclerosis. PLoS One 8:e54666. CrossRef Medline

Park P, Volianskis A, Sanderson TM, Bortolotto ZA, Jane DE, Zhuo M, Kaang BK, Collingridge GL (2014) NMDA receptor-dependent long-term potentiation comprises a family of temporally overlapping forms of synaptic plasticity that are induced by different patterns of stimulation. Philos Trans R Soc Lond B Biol Sci 369:20130131. Medline

Pickering M, O'Connor JJ (2007) Pro-inflammatory cytokines and their effects in the dentate gyrus. Prog Brain Res 163:339-354. CrossRef Medline

Pribiag H, Stellwagen D (2013) TNF-alpha downregulates inhibitory neurotransmission through protein phosphatase 1-dependent trafficking of GABA(A) receptors. J Neurosci 33:15879-15893. CrossRef Medline

Pribiag H, Stellwagen D (2014) Neuroimmune regulation of homeostatic synaptic plasticity. Neuropharmacology 78:13-22. CrossRef Medline

Purgianto A, Scheyer AF, Loweth JA, Ford KA, Tseng KY, Wolf ME (2013) Different adaptations in AMPA receptor transmission in the nucleus accumbens after short vs long access cocaine self-administration regimens. Neuropsychopharmacology 38:1789-1797. CrossRef Medline

Quan N, Whiteside M, Herkenham M (1998) Time course and localization patterns of interleukin-1beta messenger RNA expression in brain and pituitary after peripheral administration of lipopolysaccharide. Neuroscience 83:281-293. CrossRef Medline

Raison CL, Capuron L, Miller AH (2006) Cytokines sing the blues: inflammation and the pathogenesis of depression. Trends Immunol 27:24-31. CrossRef Medline

Reid AY, Riazi K, Campbell Teskey G, Pittman QJ (2013) Increased excitability and molecular changes in adult rats after a febrile seizure. Epilepsia 54:e45-e48. CrossRef Medline

Reid CA, Dixon DB, Takahashi M, Bliss TV, Fine A (2004) Optical quantal analysis indicates that long-term potentiation at single hippocampal mossy fiber synapses is expressed through increased release probability, recruitment of new release sites, and activation of silent synapses. J Neurosci 24:3618-3626. CrossRef Medline

Riazi K, Galic MA, Kuzmiski JB, Ho W, Sharkey KA, Pittman QJ (2008) Microglial activation and TNFalpha production mediate altered CNS excitability following peripheral inflammation. Proc Natl Acad Sci U S A 105:17151-17156. CrossRef Medline

Russell AS, Gulliver WP, Irvine EJ, Albani S, Dutz JP (2011) Quality of life in patients with immune-mediated inflammatory diseases. J Rheumatol Suppl 88:7-19. CrossRef Medline

Rygh LJ, Svendsen F, Hole K, Tjølsen A (2001) Increased spinal N-methylD-aspartate receptor function after $20 \mathrm{~h}$ of carrageenan-induced inflammation. Pain 93:15-21. CrossRef Medline

Sakimura K, Kutsuwada T, Ito I, Manabe T, Takayama C, Kushiya E, Yagi T, Aizawa S, Inoue Y, Sugiyama H (1995) Reduced hippocampal LTP and spatial learning in mice lacking NMDA receptor epsilon 1 subunit. Nature 373:151-155. CrossRef Medline

Sanderson JL, Dell'Acqua ML (2011) AKAP signaling complexes in regulation of excitatory synaptic plasticity. Neuroscientist 17:321-336. CrossRef Medline 
Santello M, Volterra A (2012) TNFalpha in synaptic function: switching gears. Trends Neurosci 35:638-647. CrossRef Medline

Saper CB, Sawchenko PE (2003) Magic peptides, magic antibodies: guidelines for appropriate controls for immunohistochemistry. J Comp Neurol 465:161-163. CrossRef Medline

Schmittgen TD, Livak KJ (2008) Analyzing real-time PCR data by the comparative C(T) method. Nat Protoc 3:1101-1108. CrossRef Medline

Shepherd JD, Huganir RL (2007) The cell biology of synaptic plasticity: AMPA receptor trafficking. Annu Rev Cell Dev Biol 23:613-643. CrossRef Medline

Shi SH, Hayashi Y, Petralia RS, Zaman SH, Wenthold RJ, Svoboda K, Malinow R (1999) Rapid spine delivery and redistribution of AMPA receptors after synaptic NMDA receptor activation. Science 284:1811-1816. CrossRef Medline

Stellwagen D, Malenka RC (2006) Synaptic scaling mediated by glial TNFalpha. Nature 440:1054-1059. CrossRef Medline

Stellwagen D, Beattie EC, Seo JY, Malenka RC (2005) Differential regulation of AMPA receptor and GABA receptor trafficking by tumor necrosis factor-alpha. J Neurosci 25:3219-3228. CrossRef Medline

Takeuchi T, Duszkiewicz AJ, Morris RG (2014) The synaptic plasticity and memory hypothesis: encoding, storage and persistence. Philos Trans R Soc Lond B Biol Sci 369:20130288. Medline

Thiagarajan TC, Lindskog M, Tsien RW (2005) Adaptation to synaptic inactivity in hippocampal neurons. Neuron 47:725-737. CrossRef Medline

Thomson CA, McColl A, Cavanagh J, Graham GJ (2014) Peripheral inflammation is associated with remote global gene expression changes in the brain. J Neuroinflammation 11:73. CrossRef Medline

Tsubokawa H, Oguro K, Masuzawa T, Nakaima T, Kawai N (1995) Effects of a spider toxin and its analogue on glutamate-activated currents in the hippocampal CA1 neuron after ischemia. J Neurophysiol 74:218-225. Medline

Ungless MA, Whistler JL, Malenka RC, Bonci A (2001) Single cocaine exposure in vivo induces long-term potentiation in dopamine neurons. Nature 411:583-587. CrossRef Medline

Vezzani A, Aronica E, Mazarati A, Pittman QJ (2013) Epilepsy and brain inflammation. Exp Neurol 244:11-21. CrossRef Medline

Vikman KS, Rycroft BK, Christie MJ (2008) Switch to Ca2+-permeable AMPA and reduced NR2B NMDA receptor-mediated neurotransmission at dorsal horn nociceptive synapses during inflammatory pain in the rat. J Physiol 586:515-527. CrossRef Medline

Walker AK, Budac DP, Bisulco S, Lee AW, Smith RA, Beenders B, Kelley KW, Dantzer R (2013) NMDA receptor blockade by ketamine abrogates lipopolysaccharide-induced depressive-like behavior in C57BL/6J mice. Neuropsychopharmacology 38:1609-1616. CrossRef Medline

Walker AK, Kavelaars A, Heijnen CJ, Dantzer R (2014) Neuroinflammation and comorbidity of pain and depression. Pharmacol Rev 66:80-101. Medline

Wiltgen BJ, Royle GA, Gray EE, Abdipranoto A, Thangthaeng N, Jacobs N, Saab F, Tonegawa S, Heinemann SF, O’Dell TJ, Fanselow MS, Vissel B (2010) A role for calcium-permeable AMPA receptors in synaptic plasticity and learning. PLoS One 5:e12818. CrossRef Medline

Wu LJ, Toyoda H, Zhao MG, Lee YS, Tang J, Ko SW, Jia YH, Shum FW, Zerbinatti CV, Bu G, Wei F, Xu TL, Muglia LJ, Chen ZF, Auberson YP, Kaang BK, Zhuo M (2005) Upregulation of forebrain NMDA NR2B receptors contributes to behavioral sensitization after inflammation. J Neurosci 25:11107-11116. CrossRef Medline

Zucker RS, Regehr WG (2002) Short-term synaptic plasticity. Annu Rev Physiol 64:355-405. CrossRef Medline 